2. Инклюзивное образование студентов с инвалидностью и ОВЗ с применением электронного обучения, дистанционных образовательных технологий : учеб. пособие для преподавателей сферы высшего профессионального образования, работающих со студентами с инвалидностью и ОВ3/ Под ред. Б. Б. Айсмонтаса. - М. : МГППУ, 2015. - 334 с.

3. Ишков А. Д. Проблема самоорганизации в условиях дистанционного обучения / А. Д. Ишков. Текст : электронный // Материалы Международного конгресса конференций «Информационные технологии в образовании» («ИТО-2003»). - Москва, 2003 - URL : http://ito.edu.ru/2003/III/2/III-22275.html (дата обращения 20.09.2020).

4. Малащенко Ю. М. Психолого-педагогический практикум : учебно-методический комплекс / Ю. М. Малащенко. - Новосибирск : НГПУ, 2009. - URL : https: //lib.nspu.ru/views/library/1117/web.php (дата обращения 10.09.2020).

5. Тарасова О. А. Технология интеграции лиц с ограниченными физическими возможностями в учебный процесс вуза : 13.00. : дис. ... канд. пед. наук / О. А. Тарасова. - СПб., 2004. - 134 с.

6. Шаповалова В. С. Нормативно-правовое обеспечение специального и инклюзивного образования лиц с ограниченными возможностями здоровья / В. С. Шаповалова. - Текст : электронный // Синергия. - 2016. - № 5. - URL : https://cyberleninka.ru/article/n/normativno-pravovoe-obespecheniespetsialnogo-i-inklyuzivnogo-obrazovaniya-lits-s-ogranichennymi-vozmozhnostyami-zdorovya (дата обращения 20.09.2020).

\title{
Нарыкова О.Н. \\ Роль гражданско-патриотического воспитания студентов в рамках иноязычной поликультурной образовательной среды
}

Курский государственный университет

(Россия, Курск)

doi: $10.18411 / l j-02-2021-152$

idsp: ljournal-02-2021-152

\section{Аннотация}

В статье актуализируется роль гражданского воспитания в условиях поликультурного образовательного пространства РФ, как важнейшего направления политики современного демократического государства. В рамках патриотического воспитания особо подчёркивается значимость развития навыков межкультурного общения средствами изучаемого и с учётом использования кросс-культурных и проектно-ориентированных методов и форм обучения.

Ключевые слова: гражданско-патриотическое воспитание, иноязычная поликультурная образовательная среда, высшее профессиональное образование, культура межнационального общения, этнокультурная толерантность, культуроцентризм

\section{Abstract}

In this very article the role of civil education is actualized as an integrative part of modern polycultural educational society such as Russian one and is also being regarded as an important direction of democratic state policy. The topicality of cross-cultural communicative skills development is also outlined by the researcher in the network of civic and patriotic upbringing by means of foreign language skills and on basis of cross-cultural and projectoriented forms and methods of study.

Key words: civic and patriotic education, foreign language multicultural educational environment, higher professional education, culture of interethnic communication, ethnocultural tolerance, cultural centrism

Приоритетная задача современной образовательной системы, в том числе высшего профессионального образования, заключается в воспитании молодёжи нового поколения уважительно относящейся к культурным ценностям и в формировании у будущих бакалавров и магистров всех направлений подготовки профессионально- 
значимых качеств, позволяющих эффективно выстраивать сотрудничество с представителями различных национальностей, вероисповеданий и социальных групп.

Студенческий возраст вместе с тем есть период становления активной жизненной позиции, когда происходит осознание личностью своих обязанностей, прав и возможностей, что особенно актуально в XXI в., когда огромное внимание уделяется проблемам формирования правового государства и гражданского общества, где высшей ценностью является обеспечение свободы человечества.

В сложных условиях современной многонациональной среды реализация концепции поликультурного образования является особо перспективной, поскольку суть её направлена на обеспечение признания человечеством права на своё единство и многообразие в плане нравственных и культурных аспектов. При этом, наличие полиэтнической среды социума определяет глубокую потребность в организации целенаправленной работы по формированию у всех граждан высокой культуры межнационального общения и воспитания национальной, культурной и религиозной терпимости, чему способствует взаимодействие различных языков, традиций и нравов. Таким образом, определяющую роль в направленности образовательного процесса на патриотическое воспитание студентов играют не только такие гуманитарные дисциплины как история, общество, русский язык, литература, но и непосредственно изучение ими иностранного языка. Данное требование отражено, в том числе в Примерных программах по иностранному языку.

Существует ряд законодательных документов РФ и ряд федеральных программ, таких как федеральная целевая программа «Молодёжь России», «Федеральная национальная программа» и др., в рамках, которых подчеркивается, что воспитание культуры межнационального взаимодействия в российском обществе есть важнейший компонент гражданского воспитания, предусматривающий адаптацию человека к различным ценностям в ситуации диалога культур.

Вместе с тем многие преподаватели задаются вопросом: как обеспечить формирование способности студентов к осознанию российской гражданской идентичности в поликультурном социуме на уроках иностранного языка? Достижение таких результатов представляется возможным лишь в том случае, если уроки спланированы с оптимальным учетом методических рекомендаций и на их основе приоритетным отбором методов и форм обучения, в связи с чем, преподавателям часто приходится прибегать к помощи дополнительной методической и культурологической литературы.

Актуальным представляется прибегнуть к использованию таких форм учебных заданий, как уроки - диспуты, «круглые столы», деловые и ролевые игры, а также проектная деятельность, способствующих развитию самостоятельности мышления молодёжи, способности к самоорганизации, созиданию и сотрудничеству.

Наиболее эффективные результаты достижимы в том случае, если направленность проектов будет сосредоточена на развитии у молодежи чувства эмпатии и умения понимать и принимать представителей других национальностей такими, какие они есть, т.е. способствовать становлению этнокультурной толерантности обучающихся в сочетании с чувством национального достоинства. Это и есть те необходимые качества, которые обеспечивают успешную адаптацию и самореализацию человека в обществе.

Следует подчеркнуть, что в условиях сложившейся сложной политической ситуации в мире, деформацией духовно-нравственных ценностей, обострением конфликтов на межнациональной основе, дисциплина иностранный язык имеет «колоссальный воспитывающе-познавательный потенциал» и, как ни один другой предмет, способен способствовать воспитанию у молодежи чувства терпимости к инакомыслию и их гражданско-патриотические чувства. 
Перед педагогом в свою очередь ставится ряд задач: дать обучающимся представление о культурном многообразии мира, о необходимости уважения своеобразия и уникальности каждой культуры, о важности взаимодействия и взаимообогащения культур, чтобы тем самым повысить уровень развития культуры межнационального общения студентов, а вместе с тем, развить чувство патриотизма и национального достоинства.

Метод проектной деятельности гармонично сочетаем с проведением внеаудиторных воспитательных мероприятий отличающихся своей занимательностью, увлекательностью и информативностью. Совместная организация тематических вечеров и праздников способствует сплочению студенческого коллектива, предоставляя возможность каждому реализовать свои способности и таланты.

В процессе совместных дискуссий с использованием средств изучаемого языка студенты обмениваются знаниями о национально-культурном своеобразии воспитательных систем народов в процессе самостоятельного поиска решения жизненно важных проблемных вопросов межкультурного характера. Так, например, в рамках дискуссий сопоставительного характера на основе метода проблемного изложения, студенты активно обсуждают глобальные проблемы современности, акцентируя важность межкультурного понимания.

Педагогический опыт и социальная практика подтвердили необходимость организации патриотического воспитания, в том числе на этапе обучения в высшем учебном заведении, как одного из важнейших ресурсов преодоления социальных рисков вопреки возможному росту националистических настроений и в защиту усиления национально-культурной безопасности граждан страны. Результатом чего должно стать формирование личности, преданной национально-государственным интересам, готовой трудиться на благо Родины и нести ответственность за благосостояние отчизны и способной к осуществлению стратегий конструктивного взаимодействия с представителями иных государств и этносов на основе взаимоуважения и терпимости в контексте диалога культур поликультурного общества.

Иными словами, поликультурное воспитание призвано формировать у будущих специалистов отношения к своей стране как части общемирового культурного пространства и готовности к ведению межкультурного диалога на принципах толерантности и взаимоуважения.

Гражданско-гуманистический патриотизм характерен для формирующегося информационного общества, подчеркивая ответственность всего общества целиком за обеспечение условий толерантного сосуществования представителей разных культур и укрепления межнациональных ценностей и традиций для обогащения общемировой культуры. В этом случае уровень развития критического мышления становится тем фактором, который в современных условиях не позволяет человеку выбирать сомнительные образцы массовой культуры в ущерб национальным интересам.

Сама по себе учебная деятельность в отдельно взятом вузе не отражает в полной мере устойчивую связь патриотического и поликультурного воспитания. Именно поэтому для формирования гуманистического патриотизма особую актуальность приобретает студенческая мобильность, способствующая разрушению привычных стереотипов предрассудков благодаря не только высокому уровню развития коммуникативной компетенции обучающихся, но, главным образом, благодаря устойчивому и осознанному желанию следовать своим гражданским убеждениям и ценностным ориентациям. В обратном случае, отказ от своих национальных идеалов делает человека неинтересным для представителей других культур. Студент, который не знает истории, свей страны, не дорожит ее культурным наследием и стремится утвердить лишь свою интернациональность, на самом деле рискует потерять ее.

Воспитательная работа в образовательном учреждении, будучи ориентирована на развитие нравственных гражданско-патриотических чувств личности человека, 
должна способствовать созданию среды, обеспечивающей духовную атмосферу, в которой обучающиеся смогут выстроить адекватный образ своего национальнокультурного «Я», ощутив в полной мере своё призвание и ответственность перед историей, настоящим и будущим своей страны.

Несомненно, немаловажным является и проведение профессиональноориентированных мероприятий в рамках изучения той или иной учебной дисциплины, в данном случае иностранного языка, таким образом, чтобы тематическое содержание образовательного процесса способствовало бы ознакомлению с творчеством и традициями прошлого и настоящего как своего народа, так и страны изучаемого языка.

$* * *$

1. Алипханова Ф.Н., Магомедова П.К. Формы и направления воспитательной работы педагогического вуза в воспитании патриотизма студентов // Мир науки, культуры, образования. 2013. - № 1. - С. 34-36.

2. Галактионова, Ю.Ю. Состояние системы образования в современной России и прогнозирование её дальнейшего развития / Ю.Ю. Галактионова// Аллея науки. - 2018. - Т.4 - № 1 (17). - С. 795-797.

3. Государственная программа Российской Федерации «Развитие образования на 2013-2020 годы» (Распоряжение Правительства Российской Федерации от 15.05.2013 г. № 792) [Электронный источник] / http: //base.garant.ru/70643472/ (дата обращения 29.10.2020)

4. Матвеев, В.В. Реформа высшего образования в России и перспек-тивы молодых специалистов / В.В. Матвеев// Вестник Удмурдского уни-верситета. - 2019. - № 2. - С. 43-52.

5. Микерова, Г.Г. Современные тенденции управления системой об-разования в России // Г.Г. Микерова // Современные технологии управле-ния. - 2017. - № 2-1 (12). - С. 196-201.

\section{Нургалиева А.И., Халикова Ф.Д. \\ Актуальные вопросы организации проектных и исследовательских работ по химии}

КФУ
(Россия, Казань)

doi: $10.18411 / l j-02-2021-153$

idsp: ljournal-02-2021-153

\section{Аннотация}

Со временем меняются формы и методы организации учебных занятий обучение приобретает деятельностный характер, делается упор на практическое обучение, совместную работу учащихся в группах, развитие самостоятельности учеников и собственной ответственности за принятие решений. Одной из таких форм образовательной деятельности является проектные и исследовательские работы учащихся по химии.

Ключевые слова: проектная и исследовательская деятельность, практикоориентированный подход, ФГОС, химия.

Слово «исследование» происходит от средневекового французского слова «rechercher», что означает «искать ближе». В самом общем смысле исследования включают изучение темы, чтобы узнать о ней больше.

Исследование - это творческий процесс изучения объекта или явления с определенной целью, но с изначально неизвестным результатом [2].

А.С.Обухов отмечает, что исследовательская работа - это процесс взаимной творческой деятельности двух субъектов по поиску решения определенной проблемы, в процессе которого выполняется передача культурных ценностей, итогом которого считается формирование мировоззрения [3]. Педагог предлагает формы и требования исследовательской работы, вследствие которого у учащихся развивается внутренняя мотивация приступать к каждой образующемуся перед ним вопросу с творческой позиции. 